\title{
Bilingual instruction in early childhood education, can it better develop children? \\ ${ }^{1)}$ Santri E. P. Djahimo, ${ }^{2)}$ Yulia Indahri
}

\author{
${ }^{1)}$ English lecturer, Universitas Nusa Cendana (UNDANA) Kupang, NTT Indonesia \\ ${ }^{2)}$ Senior researcher, Secretary General of DPR-RI, Jakarta, Indonesia
}

\begin{abstract}
This is a case study of teaching and learning using bilingual instruction in two schools of Early Childhood Education in Kupang-NTT, Indonesia. The aims of this study are to find out whether or not bilingual instruction in Early Childhood Education can better develop children (the outcomes) and if the issue of 'the younger, the better" in children's language acquisition in bilingual setting is acceptable and true. 4 students from one bilingual and one monolingual schools have been observed. In addition, parents and teachers of these students have also been interviewed. The data has then been analyzed qualitatively to come to the answers of the proposed questions, and the results reveal that bilingual instruction alone does not necessarily create better children unless it is supported by other factors, such as encouraging parents, professional teachers, and supporting environment. This is in a line with the findings of the issue about 'the younger, the better' in children's language acquisition, that the younger does not always mean the better. Other aforementioned factors are needed in the development of children's language acquisition. It's recommended that all parties involved in children's development can take part in developing their skills, knowledge as well as characters.

Keywords: Bilingual instruction, Early Childhood Education, Children's development, Children's Language Acquisition
\end{abstract}

\section{INTRODUCTION}

Schools have changed over time; not only in relation to the where but also to the how they are operated. Indonesian schools in particular have gone through the changings: many obsolete buildings and facilities have already been replaced by the modern ones with great management and highly qualified teachers, various textbooks and other supplementary materials, well-designed curriculum as well as other teaching tools with bilingual or even trilingual instruction, well-prepared students, and so on. Without trying to generalize, it can be said that most schools in Indonesia, especially those which are located in urban areas have already had these kinds of changings. The obvious one relates to English as a Foreign Language (EFL) which has been dominantly used in schools. Several schools have even declared themselves as "international" schools which have now been changed to Educational Cooperation Units (Satuan Pendidikan Kerja Sama), based on Indonesia regulation (Permendikbud No.31 2014).

Many studies have been conducted about the use of bilingual instruction in school levels but not many of them have looked at how it works to students' achievement, especially on the level of Early Childhood Education program. There are still gaps relate to the issue of language of instruction applied to this level of Education. Actually, we have to put more concern on looking at the answer of the question about whether or not the use of bilingual instruction can really better develop children as well as how it can develop children's language acquisition. In order to bridge the existing gaps, this study has been designed and conducted to focus on one particular issue about medium of instruction. Bilingual instruction in Early Childhood Education will be discussed in particular as the findings of this study. However, this study has been conducted only for a short period of time, therefore there are several psychological issues relate to children's development cannot be assured as some aspects of the longer term issues are beyond the scope of the study.

\section{LITERATURE REVIEW}

There are three main issues raised in this part, they are the concept of Early Childhood Education; the definition and concept of bilingual instruction, and the use of bilingual instruction in Early Childhood Education; Pros and Cons.

Many authors and researchers see Early Childhood Education with different concepts and perspectives. According to Ojala (1978a), Early Childhood Education is not only a theory but also it can be seen as a practice to be applied before the school age. Later in 1993, Professor Ojala came up with additional issue of Early Childhood Education by saying that it is the process of activity either at home or elsewhere to develop the personality of children between 0 - 
6 years of age. Another point of view states that preschool belongs to Early Childhood Education (Hujala et al., 1998) and that Early Childhood Education refers to the activities to educate under school-aged children (Karila, et al., 2001). This study has then adopted to be adapted all these concepts and created its own concept to match with its specific focus, that Early Childhood Education relates to educational activities (teaching and learning) that involve both teachers and students (children of 0-6 years of age) in school environment.

When we are talking about bilingual learners, we will definitely know that it refers to those who use their first language at home or in the community, for example, Bahasa Indonesia, and are learning various subjects through a second and/or foreign language, for instance, English, at schools (Cambridge, 2015). In this study, bilingual instruction is defined as two languages (Bahasa Indonesia and English) which are used as medium of instruction in the teaching and learning process. The two languages are not equally used but in this case, English is more dominantly used than Bahasa Indonesia. There are some positive and negative sides about bilingual education or the use of bilingual instruction in Early Childhood Education program. Mehisto (2012) is one of those who look at the positive side of using bilingual instruction to this level of students by stating that bilingual learners will gain positive benefits from this bilingual program, such as having flexible mental, gaining better understanding about different cultures, and having more opportunity for international trade. Whereas Ball (2011) argues that based on the research result, mother tongue is the basic for children to be able to learn best. This study will look into the issue of whether or not bilingual instruction in Early Childhood Education can better develop children (the outcomes).

The discussion about using bilingual instruction cannot be separated from the diversity of hypotheses in language acquisition. One of the most common belief is from the Critical Period Hypothesis (CPH) about "the younger, the better" in which children are assumed to be easier in acquiring language than adults (Lenneberg, 1967). This point has become the main ground for the use of bilingual instruction in Early Childhood Education. However, there are several critics on this CPH. One of the critics is from Singleton (1995). He agrees that the younger, the better, but conditions apply. So, the younger can only be the better only if the process occurs in the long run. He also adds that adults can also be great language acquirers even though they don't start in their critical period. Krashen (2013) also argues that language acquisition occurs when we naturally pick up a language in a sub-conscious way and this can happen not only to children but also to adults. Another issue to be raised in this study is to prove whether or not "the younger, the better" in children's language acquisition in bilingual setting is acceptable and true.

\section{METHODS}

This study is about teaching and learning using bilingual instruction in two schools of Early Childhood Education in Kupang, East Nusa Tenggara (NTT) Province and it's a case study. Generally, this study aims at answering the question of whether or not bilingual instruction in Early Childhood Education can better develop children (the outcomes). Particularly, its aim is to find out whether or not the issue of 'the younger, the better" in children's language acquisition in bilingual setting is acceptable and true.

The findings of this study will redound to the benefit of teachers, education practitioners, policy makers and other parties involved in this specific field considering that bilingual instruction in Early Childhood Education tends to be dominantly applied today. The increasing number of schools using bilingual instruction justifies the need for a deeper look into its effectiveness and advantages. Thus, the above mentioned parties that apply bilingual instruction will be able to reflect and assess the process and product they have been going through so far. Furthermore, this study will also help uncover critical issue of "the younger, the better" in children's language acquisition and so a new theory on language acquisition may be arrived at.

Four students from two schools of Early Childhood Education in Kota Kupang - NTT Province have been involved in this study which have then been grouped into two groups and observed. Group 1 consists of 2 students (student 1 , PD is a 4.8 - year - old boy and student 2, RR is a 5 - year - old girl) from Early Childhood Education uses bilingual instruction. Group 2 consists of 2 students (student 3, GL is a 5 year - old - girl and student 4, RD is a 5.1 - year - old girl) from Early Childhood Education uses monolingual instruction. Additionally, parents (with different professions) and 2 teachers (with similar qualification) of these four students have also been included in this study to be interviewed. These students have been studying in those two schools for one year.

In collecting the data, interview and observation have been used. Both have been used to validate and strengthen the collected data (methodology triangulation). The data has been collected for eight weeks. The first four weeks have been spent to collect data from group 1 (school 1) and the other 4 have been used for data collection in group 2 
(school 2).There have been 40 meetings altogether (20 meetings in each school). During those meetings, the four students have been observed; the observation has been focused on the way they learned, participated, and interacted both verbally and nonverbally in the teaching and learning process in the classroom. Note taking has been made and the results of observation have been documented to be analyzed. Several informal oral tasks have also been conducted to be able to see their language development (i.e English). Parents of these four children have also been involved in this study through interview session in order to find out what and how their children do at home to develop their English language. Teachers of both schools have also been asked about students' achievement and progress in schools. The data has then been analyzed qualitatively to come to the answers of the proposed questions. The main interpretation in this study is qualitatively explained, in order to identify and discuss the findings about whether or not bilingual instruction in Early Childhood Education can better develop children.

\section{RESULTS AND DISCUSSION}

Each group of the students has been observed for four weeks and their parents and teachers have also been interviewed, and the results show that bilingual instruction alone does not necessarily create better children unless it is supported by other factors, such as encouraging parents, professional teachers, and supporting environment. The detailed findings are as follow:

PD, student 1 of school 1_that applies bilingual instruction, develops better within four weeks. He tends to discover and explore things better than other children in his class. He understands the teacher's instruction well and can communicate in English fluently. However, his Bahasa is not as fluent as his English. According to his teacher, he's the smartest and the most active student in the classroom (which can obviously be observed easily). His mother says that he was born in Australia and spent time in there until 3 years old before moving in to Indonesia (Kupang) and directly enrolled in this school because of its "international" label. Furthermore, she informs that both of she and her husband use English in daily life communication with him because they want to maintain his English. His habits of watching English cartoon movies and playing games using English have shaped his great English ability. Another positive habit, according to his mom is listening to either his mom or his dad reading English stories for him. His oral performance in English is good and his overall knowledge of the lessons is great.

RR, student 2 of school 2_that applies bilingual instruction, doesn't develop herself within four weeks. She tends to be quiet and passive in the classroom. She even rejects to join any kind of sports because doesn't want to mingle around with her classmates. She doesn't speak much during the class and so it's not really clear whether or not she learns something from her teacher. When her teacher explains the lessons and shows how to do it, she prefers to be busy with her own activity with her objects (it can be pen, color pencils, bag, etc.). Her teacher admits that it's not easy to face her because she tends to ignore not only the lessons but also the teacher. She doesn't want to be left alone during school time so her babysitter has to accompany her, even she wants her babysitter to come to the classroom with her. Her language doesn't develop well, that's why she tends not to talk to others but her babysitter. Her mom says that she can't be treated in a hard way because she won't be able to take it. She cries easily to things she doesn't want to. Preventing her from crying, her parents almost always do whatever she wants. Her mom explains that as the only child, she needs to be spoiled. By sending her to this "international" school with English as the dominant language of instruction, her parents hope that she can have good English skill because her teacher always uses English to teach them every school day but Friday.

GL, student 3 of school 2_that applies monolingual instruction, looks great in her academic performance. Her teacher teaches her simple math and science in Bahasa Indonesia and uses English only in teaching English but not all the time during the lesson. She learns English once a week, every Friday as a local content (Muatan Lokal). In her English class, her teacher is very creative in using many kinds of games to attract the students to engage and participate in the teaching and learning process. Realizing that English can only be taught once a week, she says that it's important for her to motivate and encourage her students to study English by presenting the lessons interestingly. This student's English is well-developed during the 4 weeks and so are her math and science. She is very active in sport and tends to be inquisitive. Her teacher claims that her good English has been achieved from her parents. Both of her parents are English teachers and they insist her speak good English. Her father says that he always encourages her to join any kinds of English competition (story telling, speech delivering, and spelling bee). Other subjects are also important for her so both her mom and dad send her to join extra courses. She is literate in both English and Bahasa and always reads English stories by herself. 
$\mathrm{RD}$, student 4 of school 2_that applies monolingual instruction, is more or less similar in academic performance to the previous one. Her parents aren't English teachers but they have sent her to English course since she was 4 years of age. Her mother says that she expects her daughter to have good English because she knows how important English is. Many kids' movies and songs in English have been purchased by her parents to make her get used to the language. According to her teachers, she is a type of auditory learner because she can memorize and retain all information only by listening. It's obvious in the observation that she's playing while listening to her teacher's sample of presentation and she can eventually perform that really well.

The observations show that the use of bilingual instruction in school 1 cannot really improve the students' skills and achievement, because RR is still difficult to keep up with the lesson and cannot acquire English well. This might be because of lack of support from parents and environment. She still needs to improve her first language before being able to acquire her English as a language of instruction. It has been noted that the use of English in this school is more dominant than the use of Bahasa Indonesia. English is used from Monday to Thursday and Bahasa Indonesia takes place as the language of instruction on Friday only. This kind of bilingualism is not really clear. It can't be classified as transitional bilingual education because Bahasa Indonesia is not used here as the instruction to learn English. Classifying it as late-exit development bilingual education is also not acceptable because in this type, students' first language has to be taught first to make them easier to acquire the second and/or foreign language. This is strengthened by Catts et al. (1999); August at al. (2005) and Yesil-Dagli (2011) by arguing that in shaping children's oral language and developing their early literacy, not only second language is used but also first or native language is needed. Furthermore, there's an important point to highlight that the use of bilingual instruction for preschool-age children doesn't focus only on a second and/or foreign language but the first language as well because children still learn their native language by those ages (Ballantyne, 2008). On the other hand, GL and RD from monolingual school have shown that they can perform well in both their achievement in their lessons and their English skill. Teachers of both schools might have performed well in their teaching activities but it's obvious that the teacher of monolingual school is more creative in teaching, especially English lesson.

Based on the findings it can be concluded that being students in schools with bilingual instruction doesn't guarantee that all children will develop themselves better. The previously mentioned factors play important roles in developing students to be better. This is in a line with the findings of the issue about 'the younger, the better' in children's language acquisition, that the younger does not always mean the better. These four students are still in the category of critical period but not all can perform better result. The result of this study supports the statements of Singleton (1995) and Krashen (2013) that age matters but conditions apply. Krashen (2013) makes a good point that supports this result by stating that the younger won't be the better if children have anxiety and don't have high motivation. It can happen that two students get exactly similar input but eventually, one will get better than another. In short, the bilingual instruction itself won't do much to develop children in Early Childhood Education but other supporting factor will help the children to have better development.

\section{CONCLUSIONS}

This research provides the findings that bilingual instruction can't alone better develop children in Early Childhood Education and also the younger doesn't automatically mean the better in language development. Both have to be strengthened by other supporting factors, they are encouraging parents, professional teachers, and supporting environment. However, the limit of time has also limited the reach of findings and analysis of this study and so it opens a door and leaves a room to more extensive research on many levels, especially the one relates to psychological issues about children's development.

\section{ACKNOWLEDGEMENT}

This study has been conducted with the help of a number of people. Thanks to the principals and teachers of Leaps and Bounds and Right Start Kupang, and TK Pembina Kupang. The appreciation is also addressed to the children and their parents for their great contribution to complete this study.

\section{REFERENCES}

August, D., Carlo, M., Dressler, C., \& Snow, C. E. 2005. The critical role of vocabulary development for English language learners. Learning Disabilities Research \& Practice, 20, 50-57. 
Cambridge Professional Development Qualifications for Teaching Bilingual Learners: www.cie.org.uk/pdq retrieved on 10th July 2017.

Catts, H. W., Fey, M. E., Zhang, X., \& Tomblin, J. B. 1999. Language basis of reading and reading disabilities:

Evidence from a longitudinal study. Scientific Studies of Reading, 3, 331-361.

Hujala, E., Puroila, A-M., Parrila-Haapakoski, S., \& Nivala, V. 1998. Päivähoidosta Varhaiskasvatukseen (From Day care to Early Childhood Education). Jyväskylä: Gummerus.

Karila, K., Kinos, J., \& Virtanen, J. 2001. Varhaiskasvatuksen Teoriasuuntauksia (Early Eduvation Theory Directions). Juva: PS-Kustannus.

Krashen, Stephen. 2013. Second Language Acquisition: Theory, Applications, and Some Conjectures. Cambridge University Press.

Lenneberg, E.H. 1967. Biological Foundations of Language. Wiley. ISBN 0-89874-700-7.

Mehisto, P. 2012. Excellence in Bilingual Education: A Guide for School Principals. Cambridge: CUP/Cambridge International Examinations.

Ojala, M. 1978a. Varhaiskasvatus Tieteenä (Early Childhood Education). KASVATUS (9), 5/1978, 308-313.

Ojala, M. 1993. Varhaiskasvatus. Teoriasta Käytäntöön (Early Childhood Education. From Theory to Practice). Joensuun Korkeakoulu. Kasvatustieteiden Osaston Julkaisuja 2/1978.

Singleton, David,. \& Lengyel, Zsolt, eds. 1995. The Age Factor in Second Language Acquisition : A Critical Look at the Critical Period Hypothesis. Clevedon (England): Philadelphia. ISBN 1-85359-302-8.

Yesil-Dagli, U. 2011. Predicting ELL students' beginning first grade English oral reading fluency from initial kindergarten vocabulary, letter naming, and phonological awareness skills. Early Childhood Research Quarterly, 26, 15-29. 